\title{
ARTICLES
}

\section{The Witness Protection Mechanism of Delayed Disclosure at the Ad Hoc International Criminal Tribunals}

\author{
Sangkul Kim*
}

The ad hoc international criminal tribunals addressing the mass atrocities involving such extraordinary crimes like genocide, crimes against humanity and war crimes have developed a delicate and intricate judicial scheme of 'delayed disclosure.' Against the backdrop of the unique gravity of egregious atrocities, 'delayed disclosure' aims at respecting the fundamental interests of both the accused and the witnesses, which has turned out to be an exceptionally challenging judicial exercise. Striking a balance between the rights of the accused to have adequate time to prepare his defence on the one hand, the protection of identifying information of witnesses who may be subject to serious danger or threat requires highly disciplined judicial vigilance on the other. For the purpose of elucidating the demanding challenges involving the practice of 'delayed disclosure,' this paper explores the relevant rules and case law of the ICTY and the ICTR.

\section{Keywords}

Delayed Disclosure, Rolling Disclosure, Rights of the Accused, Witness Protection, Protective Measures, Identifying Information 


\section{Introduction}

While dealing with core international crimes such as genocide, crimes against humanity and war crimes, the international criminal tribunals would grant the accused a right to examine the witnesses against him. ${ }^{1}$ In order to exercise this right effectively, the names and identifying information of the prosecution witnesses need to be disclosed to the accused so that he can prepare his defence adequately. The international criminal tribunals thus do not permit non-disclosure of the identity of a witness (witness anonymity) at the trial stage. ${ }^{2}$ On the other hand, there are considerable number of witnesses or potential witnesses who are very reluctant to testify fearing for their safety. ${ }^{3}$ Against this background, we can see that the balancing exercise between the rights of the accused and the interests of witnesses becomes crucial at the international criminal tribunals.

The primary purpose of this research is to address the 'delayed disclosure,' one

1 See, e.g., Statute of the International Criminal Court ("ICC"), art. 67(1)(e); Statute of the International Criminal Tribunal for the Former Yugoslavia ("ICTY”), art. 21(4)(e); Statute of the International Criminal Tribunal for Rwanda ("ICTR"), art. 20(4)(e). They all provide, almost verbatim in language, the accused's right to "examine, or have examined, the witnesses against him or her [...]." For details on this right, see R. MAY \& M. Wierda, INTERNATIONAL Criminal Evidence 284-8 (2002).

2 Tadić, the first trial of the ICTY is the only exception. In this case, the Trial Chamber granted witness anonymity. See Prosecutor v. Tadić, IT-94-1-T, Decision on the Prosecutor's Motion requesting Protective Measures for Victims and Witnesses, Aug. 10, 1995 (hereinafter Tadić Decision), available at https://www.legal-tools.org/uploads/tx_ltpdb/ TadicD._ICTYTCDecisiononProsecutorsMotionRequestingProtectiveMeasures_10-08-1995_E_ 04.htm (last visited on May 8, 2016). The Trial Chamber specified the two main reasons for permitting witness anonymity in this case: (1) the fear of reprisal during an ongoing conflict; and (2) the absence of a fully-funded and operational witness protection program in the ICTY. See id. at 42 . This decision sparked intense scholarly debate. Even the senior prosecutor of the ICTY Office of the Prosecutor later acknowledged that he was "personally very uncomfortable with the notion of going forward with witnesses whose identity are not disclosed to the accused." See M. Scharf, BalKan Justice: The Story Behind the First International War Crimes Trial Since Nuremberg 108 (1997). Subsequently, however, the ICTY Trial Chambers did not follow the Tadić precedent of granting anonymity. In addition to concern for the rights of the accused, the development of the witness protection program at the ICTY also explains the judicial practice of not granting anonymity after Tadić. For details, see G. Acquaviva \& M. Heikkilä, Protective and Special Measures for Witnesses, in International Criminal Procedure: Principles and Rules 838 (G. Sluiter et al. eds., 2013); G. Boas et al, International Criminal Law Practitioner Library, Volume III: International Criminal Procedure 268-70 (2011); M. Kurth, Anonymous Witnesses before the International Criminal Court: Due Process in Dire Straits, in THE Emerging Practice of the International Criminal Court 621-26 (C. Stahn \& G. Sluiter eds., 2009); J. Pozen, Justice Obscured: The Non-Disclosure of Witnesses' Identities in ICTR Trials, 38 N.Y.U. J. INT'L L. \& PoL. 287-94 (2005-2006), available at http://nyujilp.org/wp-content/uploads/2013/02/38.1_2-Pozen.pdf (last visited on May 8, 2016); P. Chifflet, The Role and Status of the Victim, in International Criminal Law Developments in the Case LaW of the ICTY 83-7 (G. Boas \& W. Schabas eds., 2003).

3 Scharf, supra note 2, at 68. Judge Cassese once said that the judges at the ICTY were "very much aware that there may be considerable reluctance on the part of witnesses to come to the Tribunal to testify. One of our overriding concerns has been how to encourage witnesses to do this." 
of the key witness protective measures. Through the delayed disclosure mechanism, the prosecutor can temporarily keep the names and other identifying information of witnesses confidential to the accused up until the point in time as determined by a Trial Chamber, mostly sometime before the commencement of the trial. The delayed disclosure has been extensively practiced ${ }^{4}$ at the ad hoc international criminal tribunals ${ }^{5}$ under the condition that the relevant requirements stipulated in their Statute and the Rules of Procedure and Evidence ("RPE") are met. In this paper, the author will especially explore the relevant jurisprudence of the International Criminal Tribunal for the Former Yugoslavia ("ICTY") and the International Criminal Tribunal for Rwanda ("ICTR"). Due to the potentially adverse implications of the practice of withholding such critical information from the accused vis-àvis the accused's right to a fair and impartial trial, particularly the right to have adequate time for the preparation of his defence, this paper inherently reflects and incorporates adversarial tension in international criminal litigation.

Currently, applying strict parameters, the ICTY and the ICTR are taking a cautious approach in determining whether to employ the delayed disclosure mechanism. In practice, delayed disclosure takes the form of redacting (the prosecutor's side) and approving (the Chamber's side) the identifying information of witnesses from relevant materials to be disclosed to the accused, including witness statements. ${ }^{6}$

This paper is composed of six parts including short Introduction and Conclusion. Part two will discuss the rules of RPE for Delayed Disclosure. Part three will examine the preconditions for delayed disclosure, i.e., 'Exceptional Circumstances.' Part four will probe into the scope of identifying information subject to delayed disclosure. Part five will investigate the timing of full disclosure. All the arguments

4 Prosecutor v. Milosević, IT-02-54-T, Decision on Prosecution Motion for Provisional Protective Measures Pursuant to Rule 69, Feb. 19, 2002 (hereinafter Milosević Decision), ๆ 28, available at https://www.legal-tools.org/uploads/tx 1tpdb/Decision_on_Prosecution_Motion_for_provisional_Protective_Measures_pursuant_to_Rule_69.htm (last visited on May 8, 2016). Milosević Decision states: "The Trial Chamber notes with regret that the granting of such protective measures, which started out as an exceptional practice, has become almost the norm in proceedings before the Tribunal. Nonetheless this practice has followed individual applications for protective measures, not for blanket orders suppressing the identity of witnesses from the accused."

5 In this article, the term, "ad hoc international criminal tribunals" refers to the ICTY and the ICTR.

6 'Redaction' means striking out portions of documents for the purpose of not revealing sensitive and confidential information. At international criminal tribunals, the prosecutor can redact evidentiary materials only when the Trial Chamber approves each and every request of redaction. See e.g., Prosecutor v. Ruzindana, ICTR-95-1-T, Decision on the Motion filed by the Prosecutor on the Protection of Victims and Witnesses, Mar. 4, 1997 (hereinafter Ruzindana Decision), at. 3, available at https:/www.legal-tools.org/uploads/tx_ltpdb/Ruzindana-ICTRTCDecisionontheMotion FiledbytheProsecutor_04-03-1997__E_03.html (last visited on May 8, 2016). It reads: “[...] pursuant to Rule 69(A) of the Rules, non-disclosure by the Prosecutor of the identity of a victim or witness can only be administered if she has first obtained a court order for such measures from the Trial Chamber [...]." Thus, for members of the Office of the Prosecutor and the Trial Chambers, the workload involving such redaction for the purpose of delayed disclosure is staggering. 
and statements are basically inferred from the relevant case law of the ICTY and the ICTR.

\section{Rules of RPE Providing Delayed Disclosure}

The ICTY and the ICTR, in each Statute, provide the overall principle on the protection of victims and witnesses as follows:

The International Tribunal shall provide in its rules of procedure and evidence for the protection of victims and witnesses. Such protection measures shall include, but shall not be limited to, the conduct of in camera proceedings and the protection of the victim's identity. ${ }^{7}$

More specifically, the ICTY and the ICTR adopt two kinds of protective measures in respect of the identity of a witness in their jurisprudence: one is directed against the public governed by Rules 53 and 75(B) of the RPE of the ICTY and the ICTR, respectively, ${ }^{8}$ the other, against the accused, ${ }^{9}$ governed by Rules 69 and 75(A) thereof. ${ }^{10}$ More critical is the delayed disclosure of identifying information of witnesses to the accused, in respect of which Rule 69 is governing. In this context, it is noteworthy that:

7 ICTY Statute art. 22; ICTR Statute art. 21.

8 In respect of measures to prevent identifying information of witnesses from being disclosed to the public or the media, Rule 75(B) of the ICTY RPE and the ICTR RPE sets out such protective measures as: (a) Expunging names and identifying information from the tribunal's public records; (b) Non-disclosure to the public of any records identifying the victim; (c) Giving of testimony through image- or voice- altering devices or closed circuit television; and (d) Assignment of a pseudonym. On the other hand, Rule 53(A) provides that: "In exceptional circumstances, a Judge or a Trial Chamber may, in the interests of justice, order the non-disclosure to the public of any documents or information until further order." [Emphasis added]

9 Prosecutor v. Prlić et al, IT-04-74-T, Decision Establishing Guidelines for Requests for Protective Measures for Defence Witnesses, Feb. 22, 2008, at 2-3, available at https://www.legal-tools.org/uploads/tx_ltpdb/ MSC6195R0000220094.pdf. It reads: "[...] the Chamber recalls that a distinction must be made between protective measures which, on one hand, are intended to prevent disclosure of a witness's identity or location to the public [...] and, on the other hand, protective measures which are intended to delay the disclosure of a witness's identity to the other Parties to the trial [...]." See also Prosecutor v. Karadžić, IT-95-5/18-PT, Decision on Protective Measures for Witnesses, Oct. 30, 2008 (hereinafter Karadžić Decision), at 9 18, available at https://www.legal-tools.org/uploads/tx 1tpdb/Decision_on_protective_measures_for_witnesses.pdf(all last visited on May 8, 2016). [Emphasis added]

10 Rule 75(A) of the ICTY RPE and the ICTR RPE provides in almost verbatim language as follows: "A Judge or a Chamber may, proprio motu or at the request of either party, or of the victim or witness concerned, or of the Victims and Witnesses Section [or Support Unit], order appropriate measures for the privacy and protection of victims and witnesses, provided that the measures are consistent with the rights of the accused." 
What would usually be sufficient to show that a witness may be in danger or at risk if that witness's identity is directly disclosed to the public would not usually be sufficient to show that the witness may also be in danger or at risk if that witness's identity is disclosed only to the accused and the defence team - where obligations are also imposed upon the accused and the defence team in relation to further disclosure by them. ${ }^{11}$

The ad hoc tribunals have taken such two-track's approach between the restriction on disclosure to the public on the one hand and that to the accused on the other. It is mainly due to the higher threshold requirement of "[i]n exceptional circumstances" as provided in Rule 69(A) of the RPE of both tribunals vis-à-vis the restriction on disclosure to the accused. Rule 69(A) of the ICTY RPE and the same rule of the ICTR $\mathrm{RPE}$ regulate the non-disclosure of the identity of a victim or witness to the accused. Both read as follows:

ICTY RPE, Rule 69

(A) In exceptional circumstances, either party ${ }^{12}$ may apply to a Judge or Trial Chamber to order the non-disclosure of the identity of a victim or witness who may be in danger or at risk until such person is brought under the protection of the Tribunal. [Emphasis added]

(C) Subject to Rule 75, the identity of the victim or witness shall be disclosed within such time as determined by the Trial Chamber to allow adequate time for preparation of the Prosecution or Defence.

ICTR RPE, Rule 69

(A) In exceptional circumstances, either of the parties may apply to a Trial Chamber to order the non-disclosure of the identity of a victim or witness who may be in danger or at risk, until the Chamber decides otherwise. [Emphasis added]

(C) Subject to Rule 75, the identity of the victim or witness shall be disclosed within such time as determined by Trial Chamber to allow adequate time for preparation of the Prosecution and the Defence.

11 Prosecutor v. Brđanin et al, IT-99-36, Decision on Second Motion by Prosecution for Protective Measures, Oct. 27, 2000 (hereinafter Brđanin Second Decision), ๆ 18, available at https://www.legal-tools.org/uploads/tx_ltpdb/ Brdaninetal._ICTYTCDecisiononSecondMotionbyProsecutionforProtectiveMeasures_27-10-2000_E_03.htm (last visited on May 8, 2016). [Emphasis added].

12 As seen from the term 'either party,' though the delayed disclosure mechanism is available both to the prosecutor and the defence counsels, the author would address only the one from the prosecutor to the defence in view of its relative significance in practice. 
Thus, apart from the italicized phrases above, Rule 69(A) and (C) of the RPEs of both tribunals have the same language. Moreover, since it is a Trial Chamber that decides whether a victim or witness is "brought under the protection of the Tribunal," there is hardly any difference in the actual application thereof at each tribunal. In the relevant decisions of the ad hoc tribunals, 'delayed disclosure' has been generally referred to temporary non-disclosure of the identity of a victim or witness to the accused by way of redacting parts of potential evidence. ${ }^{13}$ Rules $69(\mathrm{C})$ of the ICTY RPE and the ICTR RPE provide the verbatim that the identity of the victims or witnesses which has been withheld from disclosure to the accused shall ultimately be disclosed to him "within such time as determined by Trial Chamber." Given this, the expression 'delayed disclosure' seems to precisely restrict this type of disclosure. It is thus notable that the original phrase - "in sufficient time prior to the trial" has been replaced by the current one - "within such time as determined by Trial Chamber" - for both the ICTY and the ICTR. ${ }^{14}$ This revision signifies the need to introduce the 'rolling disclosure' which would take place after the commencement of the trial. This issue will be addressed in Part five more specifically.

In the meantime, the phrase - 'may apply' - laid down in Rule 69(A) of the ICTY RPE was dealt with by the ICTY Trial Chamber in Brdanin. In this case, the Trial Chamber questioned whether the prosecutor's application for protective measures concerning a particular witness on a completely ex parte basis is warranted (i.e., whether such application can be made without giving any notice to the accused). After reviewing the apparently conflicting views between the Blaškić Trial Chamber (stating that protective measures cannot be sought ex parte) ${ }^{15}$ and the Simić Trial Chamber (stating that the ex parte application for protective measures can be made

13 The term 'delayed disclosure' has been commonly used by the Chambers of the ICTY and the ICTR. The following are examples: Prosecutor v. Simba, ICTR-01-76, Decision on Prosecution Request for Protection of Witnesses, Mar. 4, 2004 (hereinafter Simba Decision), ๆ 5, available at http://jrad.unmict.org/webdrawer/webdrawer.dll/webdrawer/ rec/192142/view/SIMBA\%20-\%20DECISION\%20ON\%20PROSECUTION\%20REQUEST\%20FOR\%20 PROTECTION\%20OF\%20WITNESSES.PDF; Prosecutor v. Gatete, ICTR-2000-61-I, Decision on Prosecution Request for Protection of Witnesses, Feb. 11, 2004 (hereinafter Gatete Decision), ๆ 4, available at http://www. worldcourts.com/ictr/eng/decisions/2004.02.11_Prosecutor_v_Gatete.pdf; Prosecutor v. Milosević, IT-02-54-T, First Decision on Prosecution Motion for Protective Measures for Sensitive Source Witnesses, May 3, 2002 (hereinafter Milosević First Decision), ๆ 8, available at $\mathrm{https}$ //www.legal-tools.org/uploads/tx_ltpdb/First_decision_on_Prosection_ Motion_for_Protective_Measures_for_Sensitive_Source_Witnesses.pdf (all last visited on May 8, 2016).; Tadić Decision, supra note 2 , at 89.

14 Such replacement took place at the occasions of revision of the RPE on July 6, 2002 (ICTR RPE) and on August 28, 2012 (ICTY RPE).

15 Prosecutor v. Blaškić, IT-95-14-T, Decision Rejecting the Request of the Prosecutor for Ex Parte Proceedings, Sept. 18, 1996, available at https:/www.legal-tools.org/uploads/tx_ltpdb/MRA1585R0000013972.pdf (last visited on May 8, 2016). 
when the person to be protected would otherwise be identified), ${ }^{16}$ the Brdanin Trial Chamber directed the prosecutor to file its justification for non-disclosure in such a way that the accused are given sufficient information to enable him to determine whether to oppose the relief sought. ${ }^{17}$ The Chamber therefore ordered that such filing should be made on a confidential basis (i.e., on an inter parte basis giving relevant notice to the accused). That is to say, "the [prosecutor's] arguments advanced to justify the protective measures sought should therefore be set out in such a way that the basis for the application is disclosed [to the accused] as far as possible without revealing the identity of the particular witness for whom the protection is sought." 18

\section{Preconditions for Delayed Disclosure: 'Exceptional Circumstances'}

As the non-disclosure principle of identifying information to the accused is closely related to his right to a fair and impartial trial, the RPEs of the ICTY and the ICTR permit it only "in exceptional circumstances." ${ }^{19}$ Rule 75(B) applicable to the disclosure of witnesses' identifying information to the public and the media does not provide any such precondition. Here, the condition of 'exceptional circumstances' contained in Rule 69(A) show the cautious mind of legislators. Indeed, once 'exceptional circumstances' are established leading to the non-disclosure for the accused, the balance between the accused's right and the protection of victims and witnesses must be struck. ${ }^{20}$ As regards this balancing exercise which depends on the

16 Prosecutor v. Simić et al, IT-95-9-PT, Decision on (1) Application by Stevan Todorović to Re-Open the Decision of 27 July 1999, (2) Motion by ICRC to Re-Open Scheduling Order of November 18, 1999, and (3) Conditions for Access to Material, Feb. 28, 2000, ๆๆ 40-41, available at https://www.legal-tools.org/uploads/tx_ltpdb/SimicBetal. ICTYTCReApplicationsRe-OpenDecision_SchedulingOrder_ConditionsforAccess_28-02-2000_E_1_02.htm. The level of discrepancy between these two cases of Blaškić and Simić has been somewhat reduced by the subsequent decision in Blaškić permitting such applications on an ex parte basis in certain circumstances. See Prosecutor v Blaškić, IT-95-14-T, Decision on the Defence Motion for Protective Measures for Witnesses D/H and D/I, Sept. 25, 1998, at 2, available at $\mathrm{https} / / / \mathrm{www}$. legal-tools.org/uploads/tx_ltpdb/Decision_on_the_Defence_Motion_for_Protective Measures_for_Witnesses_DH_and_DI.htm (all last visited on May 8, 2016).

17 Prosecutor v. Brđanin et al, IT-99-36, Decision on Third Motion by Prosecution for Protective Measures, Nov. 8, 2000 (hereinafter Brđanin Third Decision), $\uparrow \uparrow$ 10-11, available at https://www.legal-tools.org/uploads/tx_ltpdb/ MRA2378R0000019439.pdf (last visited on May 8, 2016); Brđanin Second Decision, supra note 11, at 933.

18 Brđanin Second Decision, supra note 11, at 914.

19 ICTY RPE, Rule 69(A); ICTR RPE, Rule 69(A).

20 Milosević Decision, supra note 4, at 9 23; Brđanin Third Decision, supra note 17, at 4; Brđanin Second Decision, 
facts of each case, the ICTY Trial Chambers stated that Article 20(1) of the ICTY Statute makes the rights of the accused the first consideration, and the need to protect victims and witnesses the secondary consideration. ${ }^{21}$ Article 20(1) of the ICTY Statute evidently ensures the tribunal's position that the trials are conducted "with full respect for the rights of the accused and due regard for the protection of victims and witnesses." 22 Before the ad hoc tribunals, however, the protection of victims and witnesses "are still given greater protective status than in national systems of criminal law" on account of such factors as: (1) "the complexities of the tribunal's jurisdiction"; ${ }^{23}$ (2) "the particular dangers that attach to those who give evidence

supra note 11, at 18; Prosecutorv Tadić, IT-94-1-T, Decision on the Prosecution's Motion Requesting Protective Measures for Witness R, July 31, 1996 (hereinafter Tadić Witness R Decision), at 4, available at http://icr.icty.org/ LegalRef/CMSDocStore/Public/English/Decision/NotIndexable/IT-94-1/MRA6144R0000050256.TIF (last visited on May 8, 2016).

21 Prosecutor v. Sainović et al, IT-99-37-AR65, App. Ch., Dissenting Opinion of Judge David Hunt on Provisional Release, Case No. Oct. 30, 2002, ๆ 73, available at https://www.legal-tools.org/uploads/tx_ltpdb/Ojdanicetal._IC TYACDecisiononProvisionalRelease_Diss.Op._30-10-2002_E__03.htm (last visited on May 8, 2016). It reads: "Careful consideration as to where the balance should lie in resolving the tension between the protection of victims and witnesses and the rights of the accused [...] has accepted that Article 20.1 of the Tribunal's Statute makes the rights of the accused the first consideration [...] and the need to protect victims and witnesses the secondary one [...]" See also Brđanin Third Decision, supra note 17, at 9 ; Brđanin Second Decision, supra note 11, at 18 ; Prosecutor v. Brđanin et al, IT-99-36, Decision on Motion by Prosecution for Protective Measures, July 3, 2000 (hereinafter Brđanin Decision), ๆ 30, available at https://www.legal-tools.org/uploads/tx_ltpdb/Brdaninetal._ICTYTCDecisiononMotion byProsecutionforProtectiveMeasures_03-07-2000_E_03.htm; Karadžić Decision, supra note 9, ๆ 20; Prosecutor v. Karadžić, IT-95-5/18-T, Decision on Accused's Motion for Modification of Protective Measures: Witnesses KDZ490 and KDZ492, Mar. 25, 2010 (hereinafter Karadžić 2010 Decision), ๆ 10, available at https://www.legal-tools.org/ uploads/tx_ltpdb/Decision_on_accused_s_motion_for_modification_of_protective_measures_witnesses_KDZ490_ and_KDZ492.pdf (all last visited on May 8, 2016). [Emphasis added]

22 Calling it a 'marked contrast,' the dissenting Judge Ninian Stephen in the Tadić Decision placed a significant emphasis on this contrast between the phrases 'full respect' and 'due regard' in Article 20(1). See Prosecutor v. Tadić, IT-941-T, Separate Opinion of Judge Stephen on the Prosecutor's Motion Requesting Protective Measures for Victims and Witnesses, Aug. 10, 1995, available at http://www.icty.org/x/cases/tadic/tdec/en/50810pmn.htm (last visited on May $8,2016)$. In practice, striking a balance between these competing interests is a complicated and challenging exercise. See ScHARF, supra note 2, at 108 (1997). With regard to her very controversial decision granting witness anonymity in Tadić, Presiding Judge Gabrielle McDonald said: "It was one of the toughest rulings she ever had to make in her career because she had to weigh the rights of the witnesses against the rights of the accused." For an argument against a vague and undisciplined 'balancing' between the rights of the accused and witnesses, see A. Ashworth \& M. Redmayne, The Criminal Process 49 (4th ed. 2010). (re-cited from Doorson v. Netherlands, 22 EHRR 330 (1996) of the European Court of Human Rights ("ECHR") in which the Court ruled against a criminal defendant who was deprived of an opportunity to confront an anonymous witness). ECHR in Doorson v. Netherlands observes that: "Principles of fair trial also require that in appropriate cases the interests of the defence are balanced against those of witnesses or victims called upon to testify." On the other hand, there are ECHR judgements which condemned the practice of witness anonymity such as Kostovski v. Netherlands (1989), 12 EHRR 434. For a brief description of Kostovski, see MAY \& WIERDA, supra note 1, at 283-4. For details on the 'balancing' exercise between the rights of the accused and witnesses, see F. Mumba, Ensuring a Fair Trial whilst Protecting Victims and Witnesses - Balancing of Interests?, in Essays oN ICTY Procedure and Evidence: in Honour of Gabrielle Kirk McDonald 359-71 (R. May et al. eds., 2001). [Emphasis added]

23 Milosević Decision, supra note 4, at 923. 
in proceedings before the tribunal", ${ }^{24}$ and (3) the lack of a comprehensive witness protection program at the tribunals' disposal. ${ }^{25}$

Rule 69(A) of the ICTY and the ICTR requires the prosecutor to establish 'exceptional circumstances' before getting the permission to redact identifying information from witness statements. The 'exceptional circumstances' are said to be an extreme nature of the danger and risk that a victim or witness may face should it become known that he or she will testify in the proceedings. ${ }^{26}$ In interpreting the term "in exceptional circumstances," the ICTY Trial Chambers set out the criteria for ordering the non-disclosure as follows: ${ }^{27}$

(a) Objective likelihood of interference or intimidation vis-à-vis the witness resulting from disclosure to the accused;

(b) Specific rather than general basis for a danger or risk relating to particular witnesses; and

(c) The length of time before the trial at which the identity of the witnesses must be disclosed to the accused. (the greater the period between the disclosure of identity and the giving of testimony, the greater the potential for interference with the witness; the time allowed for preparation must be time before trial commences rather than before the witness gives evidence.)

Meanwhile, the ICTR Trial Chamber proclaimed that the genocide in Rwanda in 1994 and the subsequent volatile security situation there are clearly 'exceptional circumstances' as contemplated by Rule 69(A). The Chamber, in Bagosora et al., further laid down the parameters for granting protective measures to witnesses

26 Prosecutor v. Milosević, IT-02-54-T, Second Decision on Prosecution Motion for Protective Measures for Sensitive Source Witnesses, June 18, 2002 (hereinafter Milosević Second Decision), ๆ 13, available at https://www.legal-tools. org/uploads/tx_ltpdb/Second_Decision_on_Prosecution_Motion_for_Protective_Measures_for_Sensitive_Source_ Witnesses.pdf (last visited on May 8, 2016); Milosević First Decision, supra note 13, at 98.

27 Karadžić Decision, supra note 9, at $\uparrow 19$; Prosecutor v. Stanisić et al, IT-03-69-PT, Decision on Confidential Prosecution Motions for Protective Measures, Oct. 26, 2004 (hereinafter Stanisić Decision), at 4, available at http:/ icr.icty.org/LegalRef/CMSDocStore/Public/English/Decision/NotIndexable/IT-03-69/MRA8962R0000102121.TIF (last visited on May 8, 2016); Milosević Second Decision, supra note 26, at 9 7; Milosević First Decision, supra note

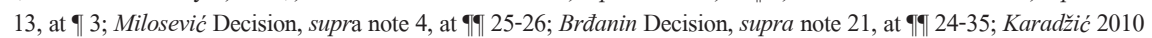
Decision, supra note 21, at 9. For details on the non-disclosure practice of the ICTY under Rule 69(A), see Chifflet, supra note 2 , at 90-4. 
under Rule 75 in accordance with the Tadic Trial Chamber decision ${ }^{28}$ as follows: ${ }^{29}$

(a) The testimony of the witness must be relevant and important to the party's case;

(b) There must be a real fear for the safety of the witness and an objective basis underscoring the fear;

(c) Any measure taken should be strictly necessary.

Following the criteria, the ICTY and the ICTR discussed the subsequent decisions on 'delayed disclosure' pursuant to Rule 69(A) focusing on both the question of a real fear for the safety of a witness or his or her family, and an objective basis for that fear. ${ }^{30}$ In fact, the accused's right to a fair trial can be curtailed only by a genuine fear for the safety of the witness or members of his or her family. ${ }^{31}$ The Brdanin Trial Chamber elucidated that:

The fears of the potential witness himself that he may be in danger or at risk are not in themselves sufficient to establish any real likelihood that he may be in danger or

28 Tadić Decision, supra note 2, at 9 - 62-66. It set out the following preconditions as: (1) there must be real fear for the safety of the witness or her or his family; (2) the testimony of the particular witness must be important to the Prosecutor's case; (3) the Trial Chamber must be satisfied that there is no prima facie evidence that the witness is untrustworthy; (4) the ineffectiveness or non-existence of a witness protection programme is another point that has been considered in domestic law and has a considerable bearing on any decision to grant anonymity in this case; (5) any measures taken should be strictly necessary. It should be noted, however, that these preconditions were set forth when the Trial Chamber was discussing the prayers (8) and (11)(a) of the Prosecution's requests seeking 'anonymity,' whereby the identifying information of victims and witnesses would not be disclosed to the accused and his counsel at all throughout the trial.

29 Prosecutor v. Bagosora et al, ICTR-96-7-I, Decision on the Extremely Urgent Request Made by the Defence for Protection Measures for Mr. Bernard Ntuyahaga, Sept. 13, 1999 (hereinafter Bagosora Decision), ๆ 28, available at https://www.legal-tools.org/uploads/tx_ltpdb/doc15211_02.pdf; Prosecutor v. Renzaho, ICTR-97-31-I, Decision on the Prosecutor's Motion for Protective Measures for Victims and Witnesses to Crime Alleged in the Indictment, Aug. 17, 2005 (hereinafter Renzaho Decision), ๆ 7, available at https://www.legal-tools.org/uploads/tx_ltpdb/Renzaho-ICT RTCDecisionontheProsecutorsMotionforProtectiveMeasures_17-08-2005_E_04.html; Prosecutor v. Ngirabatware, ICTR-99-54-T, Decision on Prosecution's Motion for Special Protective Measures for Prosecution Witnesses and Others, May 6, 2009 (hereinafter Ngirabatware Decision), ๆๆ 15-17, available at https://www.legal-tools.org/uploads/ tx_1tpdb/090506_1_07.pdf(all last visited on May 8, 2016).

30 Ngirabatware Decision, supra note 29, at 9 15. See also Gatete Decision, supra note 13, at 9 4. It states: "These fears may be expressed by persons other than the witnesses themselves." [Emphasis added]

31 Prosecutor v. Šešelj, IT-03-67-PT, Decision on Prosecution's Sixth Motion for Protective Measures for Witnesses, Dec. 8, 2005 (hereinafter Šešelj Decision), at 2-3, available at https://www.legal-tools.org/uploads/tx_ltpdb/Seselj-ICTYT CDecisiononProsecutionsSixthMotionforProtectiveMeasuresforWitnesses_08-12-2005_E_04.htm; Tadić Witness R Decision, supra note 20, at 9 ; Prosecutor v. Mrksić et al, IT-95-13/1-PT, Decision on Confidential Prosecution Motions for Protective Measures and Non-Disclosure and Confidential Annex A, Mar. 9, 2005, at 4-5, available at https://www.legal-tools.org/uploads/tx_ltpdb/Mrksicetal-ICTYTCDecisiononConfidentialProsecutionMotionsforProtec tiveMeasuresandNondisclosureandConfidentialAnnexA_09-03-2005_E_02.htm (all last visited on May 8, 2016). 
at risk from such a disclosure to the defence, and something more than that must be demonstrated before an interference with the right of the accused to know that identity is warranted. What is required is that there be some objective foundation for those fears. $^{32}$

To sum up, in order to decide the applicability of Rule 69(A) for the delayed disclosure mechanism, the following three conditions should be generally met in conjunction with each other:

(a) 'Exceptional circumstances' (encompassing the items 2 and 3 below);

(b) 'Real fear' for the safety and an objective basis for that fear to establish the likelihood that a witness may be in danger or at risk;

(c) The protective measure taken being strictly necessary (in other words, if a less restrictive measure can secure the required protection, that measure should be applied)

In this respect, the Trial Chamber of the ICTY in Brdanin stresses that, to be exceptional, the circumstances must go beyond the general circumstances in the former Yugoslavia before the Tribunal was established. ${ }^{33}$ In this case, the prosecutor relied not only upon the facts of the particular case, but also upon "the facts and circumstances concerning Tribunal cases generally" to justify the delayed disclosure of the identification and whereabouts of every person who had made the relevant statements. ${ }^{34}$ On this matter, the Trial Chamber observed that the prevailing circumstances within the former Yugoslavia could not by themselves amount to the exceptional circumstances. ${ }^{35}$ The Trial Chamber also underscored that the evidence of the specific risks faced by an individual victim or witness in establishing the existence of the exceptional circumstances is a significant threshold requirement for the application of the Rule 69(A). [Emphasis added] The prosecutor therefore must establish such exceptional circumstances on an individual basis, i.e., with regard to each and every witness. ${ }^{36}$

32 Brđanin Third Decision, supra note 17 , at 13.

33 Brđanin Decision, supra note 21, at 911 . [Emphasis added]

34 Id. at 8.

35 Id. at 11. The Trial Chamber in Brđanin holds the same lotic in this decision. See id. at 26: It states: The examples of violations in the four cases following (in a temporal sense only) the disclosure of the identity of the witnesses to the defence are accompanied by the prosecution's assertion that they show "a history of violations in virtually every case that has been brought before this Tribunal." "This piece of hyperbole does not assist."

36 Milosević Decision, supra note 4, at - 24; Brđanin Decision, supra note 21, at 11 ; Prosecutor v. Gotobina, IT-01-45PT, Decision on Prosecution Motion for Non-Disclosure to Public of Materials Disclosed Pursuant to Rules 66 and 68 , July 14, 2006, available at https:/www.legal-tools.org/uploads/tx_ltpdb/Gotovina-ICTYTCDecisiononProsecutionMo 
Namely, bearing in mind the hampering effects of 'delayed disclosure' vis-à-vis the accused's ability to investigate evidence against him, the prosecutor "is required to make a showing of exceptional circumstances with respect to each witness for whom - or each document for which - it seeks redaction." 37 Thus, a blanket protection is not available under Rule 69(A). In this connection, the Brđanin Trial Chamber emphasized the importance of specific evidence in relation to particular witnesses as follows:

The Trial Chamber accepts that, once the defence commences (quite properly) to investigate the background of the witnesses whose identity has been disclosed to them, there is a risk that those to whom the defence has spoken may reveal to others the identity of those witnesses, with the consequential risk that the witnesses will be interfered with. But it does not accept that, absent specific evidence of such a risk relating to particular witnesses, the likelihood that the interference will eventuate in this way is sufficiently great as to justify the extraordinary measures which the prosecution seeks in this case in relation to every witness. ${ }^{38}$

For appraising the particular risks against each individual witness, the ICTY Trial Chamber in Milosević placed special emphasis on whether the witness' prospective testimony concerns the (1) "matters bearing directly on the criminal responsibility of the accused"; and/or (2) "matters that relate to high level operations of government agencies, or to perpetrator groups identified in the indictments." 39 The Chamber also took into account the expected effect of permitting delayed disclosure which would facilitate the relocation process of witnesses seeking thereof in connection with their evidence. ${ }^{40}$ As regards the assessment of the risks, a series of decisions in Brdanin articulated more detailed standards for analysis. Stressing that some objective foundation for the fear as well as exceptional circumstances were required,

tionforNon-DisclosuretoPublicofMaterialsDisclosedPursuanttoRules66and68_14-07-2006_E_ $\quad$ 02.htm (last visited on May 8, 2016).

37 Milosević Decision, supra note 4, at 924 ; Brđanin Decision, supra note 21, $\uparrow \uparrow 11$ \& 28. [Emphasis added]

38 Brđanin Decision, supra note 21, at -28 . [Emphasis added].

39 Prosecutor v. Milosević, IT-02-54-T, Decision on Prosecution Motion to Amend Witness List and for Protective Measures for Sensitive Source Witnesses, Mar. 13, 2003 (hereinafter Milosević 13 March 2003 Decision), ๆ 12, available at https://www.legal-tools.org/uploads/tx_ltpdb/Decision_on_Prosecution_Motion_to_Amend_Witness_ List and for_Protective_Measures_for_Sensitive_Source_Witnesses.htm; Milosević Second Decision, supra note 26, 13; Milosević First Decision, supra note 13, 8; Prosecutor v. Perisić, IT-04-81-PT, Decision on Prosecution Motion for Protective Measures for Witnesses, May 27, 2005 (hereinafter Perisić Decision), at 2, available at https://www. legal-tools.org/uploads/tx_ltpdb/Perisic-ICTYTCDecisiononProsecutionMotionforProtectiveMeasuresforWitness es_27-05-2005_E_05.htm (last visited on May 8, 2016).

40 Milosević First Decision, supra note 13, 8; Milosević 13 March 2003 Decision, supra note 39, at $\uparrow 12$. 
the Brđanin Trial Chamber observed that "the mere fact that there will be some [members of another ethnic group] also living in the area to which [a witness] will be returning" does not in itself establish a justified fear and exceptional circumstance. ${ }^{41}$ In this context, the Trial Chamber enunciated that the following information would be useful for its consideration:

- whether the evidence of a witness will directly implicate the accused; ${ }^{42}$

- the ethnicities of a witness and the accused; ${ }^{43}$

- the identity of the town in which a witness is currently living; ${ }^{44}$

- the identity of the town to which a witness intends to return; ${ }^{45}$

- the circumstances in the town to which a witness intends to return; ${ }^{46}$

- the circumstances in the municipality in which the town a witness intends to return is located; ${ }^{47}$

- whether a witness intends to return to an area in which any investigation on behalf of the accused would necessarily have to take place; ${ }^{48}$ and

- whether the family of a witness lives in an area in which any investigation on behalf of the accused would necessarily have to take place. ${ }^{49}$

On the other hand, the ICTR took a less strict approach with regard to the precondition of 'exceptional circumstances.' Comparing to the ICTY approach requiring specific evidence for assessing the objective grounds of the danger or risk on an individual basis, the ICTR took rather a general approach. As mentioned above, the Bagosora et al Trial Chamber declared that "the genocide that occurred in Rwanda during 1994 and the subsequent volatile security situation in Rwanda are clearly exceptional circumstances contemplated by Rule 69(A). ${ }^{, 50}$ In addition, the Renzaho Trial Chamber

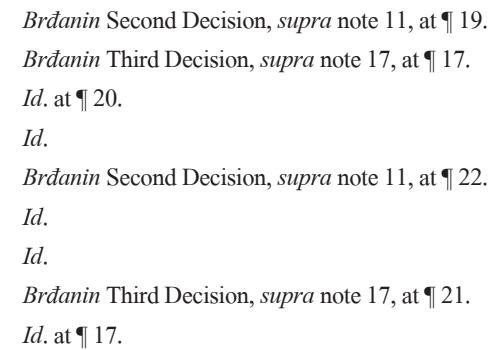

50 Bagosora Decision, supra note 29, 28. Other decisions affirming the existence of exceptional circumstances on the basis of the general volatile security situation in Rwanda and in neighboring countries are: Prosecutor v. Karemera et $a l$, ICTR-98-44-R75, Order on Protective Measures for Prosecution Witnesses Articles 19, 20 and 21 of the Statute; Rule 75 of the Rules of Procedure and Evidence, Dec. 10, 2004, at 2, available at http:/www.worldcourts.com/ictr/ eng/decisions/2004.12.10_Prosecutor_v_Karemera.pdf; Prosecutor v. Zigiranyirazo, ICTR-2001-73-1, Decision on the Prosecutor's Motion for Protective Measures for Victims and Witnesses, Feb. 25, 2003, 9, available at https://www. 
admitted that: "The Chamber is not in a position to evaluate the relevance of the testimony of individual witnesses" because of the blanket protection requested by the prosecutor. It even approved such "blanket protection for all victims and potential witnesses" on the basis of an evaluation of "the fear for the safety of witnesses in light of the general security situation both within and outside Rwanda."51 In this decision, the Trial Chamber more specifically observed that: (1) "There have been frequent violent incidents perpetrated against genocide victims and potential witnesses in Rwanda"; (2) "The security situation [in Rwanda] still remains dangerous for potential genocide witnesses"; (3) "The migration of large numbers of potential Gacaca accused persons to countries neighbouring Rwanda"; and (4) "The fact that supporters and family members of persons currently indicted or accused before the Tribunal might be living in these countries. ${ }^{, 52}$ Both ICTR Trial Chambers in Simba and Gatete also accepted the establishment of exceptional circumstances taking into account the evidence of (1) "the volatile security situation in Rwanda" and (2) "potential threats against Rwandans living in other countries." 53 The Trial Chambers subsequently stated:

This situation could give rise to a justified and real fear that disclosure of their participation in the proceedings of this Tribunal would threaten their safety and security. Accordingly, exceptional circumstances have been established warranting delayed disclosure of the identity of witnesses to the Defence, and non-disclosure to the public. ${ }^{54}$

It should be noted, however, that the recent trend is heading for a more cautious approach towards the 'generalized fears,' in spite of sometimes quite an ambivalent and even self-contradictory manner. ${ }^{55}$

legal-tools.org/uploads/tx_ltpdb/International_Criminal_Tribunal_for_Rwanda_5d9ce1.pdf; Prosecutor v. Rukundo, ICTR-2001-70-I, Decision on the Prosecutor's Motion for Protective Measures for Victims and Witnesses, Oct. 24, 2002, I 15, available at https://www.legal-tools.org/uploads/tx_ltpdb/Rukundo-ICTRTCDecisionontheProsecutors MotionforProtectiveMeasures_24-10-2002_E_03.html; Prosecutor v. Nteziryayo, ICTR-97-29-T, Decision on the

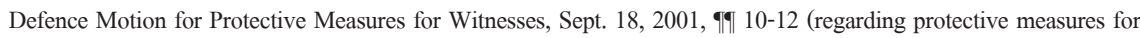
Defence witnesses), available at https://www.legal-tools.org/uploads/tx_ltpdb/doc24217_01.PDF (all last visited on May 8, 2016).

51 Renzaho Decision, supra note 29, at 99.

$52 I d$. 11. In relation to the items (3) and (4), it should be considered that, in this case, the ICTR Prosecution seeks protective measures for three categories of victims and potential witnesses: those who live in Rwanda; those who live outside Rwanda; and those who reside outside Africa.

53 Simba Decision, supra note 13, \4; Gatete Decision, supra note 13, at 94.

54 Id.

55 It is certainly confusing to see that, while criticizing the 'generalized manner' towards 'generalized fears," the Ngirabatware Trial Chamber makes a conclusion "in light of the general security situation" as follows: "In determining 


\section{The Scope of Identifying Information for Delayed Disclosure}

The relevant rules of the ad hoc tribunals do not articulate the scope of identifying information to be subject to delayed disclosure. The ICTY case law authorizes that the prosecutor may, in fulfilling its disclosure obligations under Rules 66 and 68, redact the statements, affidavits and formal statements of victims, witnesses and potential witnesses: ${ }^{56}$

(a) all information which discloses, or might lead to the disclosure of, the current whereabouts of the maker of any such document and/or his or her family;

(b) all information contained within such documents which discloses, or might lead to the disclosure of, the current whereabouts of other individuals named within them who have made witness statements which the prosecutor has already disclosed or which it intends to disclose; and

(c) all information contained within such documents which discloses, or might lead to the disclosure of, the current whereabouts of other individuals who are named in such documents, other than those individuals who are described in any document as having been present at any of those events referred to in the documents which are or which may be relevant to the issues in the trial.

whether the witness' fear is justified, the representations made by the parties must be examined in the context of the broader security situation affecting the concerned witness. However, generalized fears are not in themselves sufficient to establish a real likelihood of danger without an objective basis to substantiate these fears. [...] The Chamber notes the generalized manner in which the Prosecution submitted its request for protective measures, without distinguishing between the different type of witnesses and their different circumstances. The Chamber urges the Prosecution in future motions to distinguish between different categories of witnesses. However, in light of the disclosure of confidential information of the witnesses to the Defence, and in accordance with previous decisions issued by this Chamber [citing Renzaho Decision], the Chamber will evaluate the fear for the safety of witnesses in light of the general security situation within and outside Rwanda and decide whether measures are necessary to secure the desired level of protection." Ngirabatware Decision, supra note at 29, at 9ף 16-18. [Emphasis added]

56 Prosecutor v. Boškoski et al., IT-04-82-PT, Decision on Prosecution's Motion for Protective Measures for Victims and Witnesses, June 20, 2005, at 2, available at https://www.legal-tools.org/uploads/tx_ltpdb/Decision_on_Johan_ Tarculovski_s_Motion_for_Provisional_Release_2.htm; Prosecutor v. Boškoski et al, IT-04-82-PT, Interim Decision on Prosecution's Motion for Protective Measures for Victims and Witnesses, Apr. 28 2005, at 2, available at https:// www.legal-tools.org/uploads/tx_ltpdb/Interim_Decision_on_Prosecution_s_Motion_for_Protective_Measures_for Victims_and_Witnesses.htm; Prosecutorv. Šešelj, IT-03-67-PT, Decision on Prosecution's Motion for Non-Disclosure of Names and Other Identifying Information, May 27, 2005, at 2-3, available at https://www.legal-tools.org/uploads/ tx_ltpdb/Seselj-ICTYTCDecisiononProsecutionsMotionforNondisclosureofNamesandOtherIdentifyingInformati on 27-05-2005 E $\quad$ 04.htm; Prosecutor v. Čermak et al., IT-03-73-PT, Decision and Order on Prosecution's Motion for Protective Measures for Victims and Witnesses, Apr. 1, 2004, ๆ 33, available at https://www.legal-tools.org/ uploads/tx_ltpdb/Cermaketal-ICTYTCDecisionandOrderonProsecutionMotionforProtectiveMeasuresforVictimsandWi tnesses_01-04-2004_E__02.htm (all last visited on May 8, 2016). [Emphasis added] 
In general, the ICTY and the ICTR have permitted to react names, addresses, whereabouts, and other identifying information from witness statements. ${ }^{57}$ The previous address to which a witness may return has also been regarded as identifying information. ${ }^{58}$

\section{The Timing of Full Disclosure}

When the prosecutor must disclose the formerly withheld and redacted identifying information of a witness to the accused? Rule 69(C) of the RPE of both tribunals provides:

Subject to Rule 75, the identity of the victim and witness shall be disclosed within such time as determined by the Trial Chamber to allow adequate time for preparation of the Prosecution or Defence.

Before the relevant revision of the RPE in 2002 (ICTR) and in 2012 (ICTY), Rule 69 provided that where the non-disclosure of the identity of a victim or witness has been approved by a Trial Chamber in accordance with Rule 69(A), the identity of the victim or witness should be ultimately disclosed to the accused "in sufficient time prior to the trial to allow adequate time for preparation of the defence." Basically, Rule 69(C) was revised in 2002 (ICTR) and 2012 (ICTY) replacing the phrase "in sufficient time prior to trial" with "as determined by the Trial Chamber" in order to introduce the 'rolling disclosure' mechanism. As to the pre-revision wording, particularly, regarding the term 'sufficient time' before the revision, the ICTY Trial Chamber in Brdanin observed that it was not possible "to lay down in advance any particular period which would be applicable to all cases," be determined after the protective measures are in place." ${ }^{\prime 60}$ In determining a specific time period in this context, the ICTY Chambers considered such items as: (1) the

57 See especially, Simba Decision, supra note 13, at 8 (disposition). In relation to the non-disclosure to the public, see Prosecutor v. Milutinović, IT-99-37-PT, Decision on Prosecution's Motion for Protective Measures, July 17, 2003, at 3, available at http:/icr.icty.org/LegalRef/CMSDocStore/Public/English/Decision/NotIndexable/IT-99-37/ MRA4312R0000204811.tif (last visited on May 8, 2016).

58 Brđanin Second Decision, supra note 11 , at 933.

59 Brđanin Decision, supra note 21, at 938.

60 Id. 
number of witnesses to be investigated by the Defence; ${ }^{61}(2)$ the circumstances under which that investigation will have to take place; ${ }^{62}$ and (3) the category in which a witness in question falls (to be decided mainly on the basis of the nature and content of evidence that the witnesses is expected to present at trial). ${ }^{63}$ Here, items (1) and (2) are related to the capability and resources of the accused and his advocate(s) vis-à-vis their pre-trial investigation. Item (3) needs more explanation. For determining the length of time before the trial in the context of Rule 69(C), the Brdanin Trial Chamber stated that the knowledge of the identities of the witnesses whose prospective testimony would not directly implicate the accused would do little to assist the accused in his preparation for the trial. ${ }^{64}$ To the contrary, the Chamber opined that the witnesses whose identity is of much greater importance to the accused are those who would directly implicate him. ${ }^{65}$ In this regard, the Trial Chamber declared that a clear identification of the nature and content of evidence which each of the witnesses is to present at trial should be provided, because it would enable the Chamber to make an informed decision on the categories into which the potential evidence of each witness would fall, and thereby to determine the full disclosure time of the previously redacted identifying information. ${ }^{66}$ According to the case laws of the ICTY, so far, the prosecutor should provide the accused with un-redacted materials pursuant to Rule 69(C) "not later than 30 days before the commencement of the trial." $" 67$

As an exception, however, the ICTY, in Milosević decided almost verbatim that the disclosure of previously redacted identifying information of witnesses should be made to the "amici curiae not less than 30 days, and to the accused and his appointed associates not less than 21 days, before the witness is expected to testify." "Evidently,

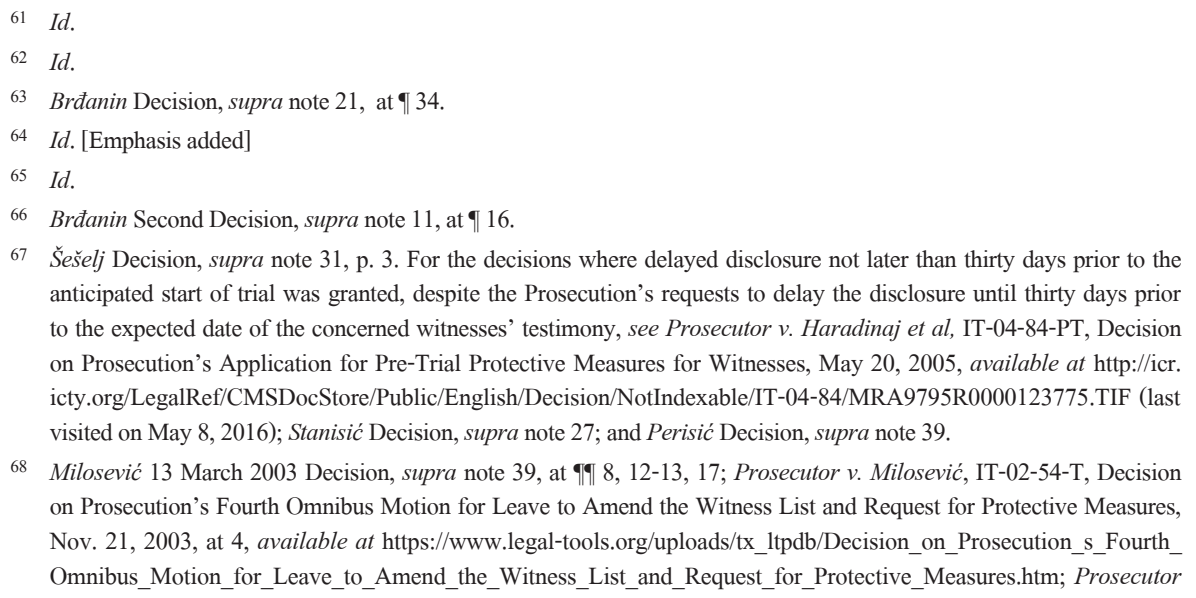
anticipated start of trial was granted, despite the Prosecution's requests to delay the disclosure until thirty days prior to the expected date of the concerned witnesses' testimony, see Prosecutor v. Haradinaj et al, IT-04-84-PT, Decision on Prosecution's Application for Pre-Trial Protective Measures for Witnesses, May 20, 2005, available at http://icr. icty.org/LegalRef/CMSDocStore/Public/English/Decision/NotIndexable/IT-04-84/MRA9795R0000123775.TIF (last visited on May 8, 2016); Stanisić Decision, supra note 27; and Perisić Decision, supra note 39.

68 Milosević 13 March 2003 Decision, supra note 39, at $\uparrow$ 甲 8, 12-13, 17; Prosecutor v. Milosević, IT-02-54-T, Decision on Prosecution's Fourth Omnibus Motion for Leave to Amend the Witness List and Request for Protective Measures, Nov. 21, 2003, at 4, available at https://www.legal-tools.org/uploads/tx_ltpdb/Decision_on_Prosecution_s_Fourth_ Omnibus_Motion_for_Leave_to_Amend_the_Witness_List_and_Request_for_Protective_Measures.htm; Prosecutor 
this conclusion made by the Milosević Trial Chamber appears to be an unequivocal violation of the pre-2012 version of Rule 69(C) which contains the phrase, "in sufficient time prior to the trial." At this juncture, the function of Rule 75(A) in connection with Rule 69(C) through the phrase "[s]ubject to Rule 75" deserves our attention mainly because the phrase may open a gate for the non-disclosure stipulated in Rule 69(A) to be temporarily extended into the trial phase. ${ }^{69}$ Through this gate, the Trial Chamber in Milosević permitted a "complete non-disclosure until a time well into the trial," which was "extraordinary in nature" and "go beyond the normal ambit of Rule 69."70 This conclusion was made on the basis of the "particular security risks which attach to these witnesses," and the "important nature of the testimony" expected to be given by them. ${ }^{71}$ In rendering this decision, the Trial Chamber also considered the signed statements of the investigators of the Office of the Prosecutor setting out in detail the circumstances of each witness. ${ }^{72}$ Other Trial Chambers also followed the mode of full disclosure being delayed until 30 days prior to the date on which a witness is expected to testify. ${ }^{73}$ It is thus correct to say that a 'rolling disclosure' has been operative at the ICTY, thereby extending the effect of delayed-disclosure into the trial phase. In view of the complexity and the length of the trial at the ad hoc tribunals particularly relating to the cases involving

v. Milosević, IT-02-54-T, Decision on Prosecution's Motion for Leave to Add Witness C-070 to the Witness List and for Protective Measures, Oct. 7, 2003, at 2, available at https://www.legal-tools.org/uploads/tx_ltpdb/Decision_on_ Prosecution_s_Motion_for_Leave_to_Add_Witness_C-070_to_the_Witness_List_and_for_Protective_Measures. htm; Prosecutor v. Milosević, IT-02-54-T, Decision on Prosecution's Motion for Leave to Add Witness B-225 and C-057 to the Witness List and for Protective Measures, Aug. 27, 2003, at 2, available at https://www.legal-tools. $\operatorname{org} /$ uploads/tx_ltpdb/Decision_on_Prosecution_s_Motion_for_Leave_to_Add_Witnesses_B25_and_C-057_to_the Witness_List_and_Request_Protective_Measures.pdf; Prosecutorv. Milosević, IT-02-54-T, Decision on Prosecution's Third Omnibus Motion for Leave to Amend the Witness List and Request Protective Measures for Sensitive Source Witnesses, July 8, 2003, at 2; Milosević Second Decision, supra note 26, at 17(1)(c); Milosević First Decision, supra note 13, at 13(1)(c); Prosecutor v. Milosević, IT-02-54-T, Decision on Prosecution Motion to Exempt Witness Statement from Trial, Apr. 26, 2002, at 1, available at https://www.legal-tools.org/uploads/tx_ltpdb/Decision_on_ Prosecution_to_Exempt_Witness_Statements_from_Trial_Chamber_s_Order_of_21_January_2002.pdf (all last visited on May 8, 2016). [Emphasis added]

69 See Milosević Second Decision, supra note 26, at 9. It states: "The Trial Chamber has only, at this stage, to determine the applicability of Rule 75 to the extent that non-disclosure extends into the trial.

70 Milosević Second Decision, supra note 26, at 10.

71 Milosević 13 March 2003 Decision, supra note 39, at $\uparrow 13$.

72 Id.

73 See Prosecutor v. Krajišnik et al., IT-00-39 \& 40-PT, First Decision on Prosecution's Motion for Protective Measures for Sensitive Source Witnesses, May 24, 2002, 15, available at http:/icr.icty.org/LegalRef/CMSDocStore/Public/ English/Decision/NotIndexable/IT-00-39\%2340/MRA5279R0000042036.TIF (last visited on May 8, 2016); Prosecutor v. Martić, IT-95-11-PT, Decision on Prosecution's Motion to Amend its Rule 65ter Witness List, Dec. 9, 2005. (It states: "10 days before the witness is expected to testify"); Prosecutor v. Mrksić et al., IT-95-13/1-T, Decision on Prosecution's Additional Motion for Protective Measures of Sensitive Witnesses, Oct. 25, 2005. 
multiple defendants, it seems unavoidable to introduce the rolling disclosure mechanism.

Meanwhile, Rule 69(C) of the ICTR RPE provides that: "The identity of the victim or witness shall be disclosed within such time as determined by Trial Chamber to allow adequate time for preparation of the Prosecution and the Defence." With regard to the term, 'adequate time,' the ICTR Trial Chamber stated:

What is 'adequate' must be assessed in light of the rights of the Accused set out in Articles 19 and 20 of the Statute while also considering the needs and vulnerability of witnesses expressed in Article 21 of the Statute. Article 19 expressly requires accommodation of the rights of the accused and the interests of witnesses and victims. $^{74}$

According to the Trial Chamber in Gatete, "the amount of time that will afford the Defence an adequate opportunity to prepare depends largely on the factual circumstances of each case, as is reflected in the variety of the periods of disclosure ordered from case to case." ${ }^{, 75}$ It also confirms that "the vulnerability of the witness or witnesses and the nature of the threat in the particular case must be weighed against the impact of the particular period of non-disclosure on the ability of the Defence to prepare." $^{\text {76 }}$

As mentioned above, Rule 69(C) of the ICTR RPE, which formerly ordered the prosecutor to provide full disclosure before the commencement of trial, was amended on July 6, 2002 to expressly introduce the 'rolling disclosure' mechanism. ${ }^{77}$ 'Rolling disclosure' means the system of disclosure of previously withheld identifying information of a witness to the accused a certain number of days (as set by a Trial Chamber) prior to the testimony of the witness at trial. In terms of 'rolling disclosure,' the ICTR Chambers have taken a careful approach because "not only does rolling disclosure shorten the period of preparation for the Defence provided for in Rule 66(A)(ii), its effect is that the trial will begin, and Prosecution witnesses will be heard, before the Defence knows the names of all Prosecution witnesses or is

\footnotetext{
Simba Decision, supra note 13, at 95.

Gatete Decision, supra note 13 , at 9.

Id.

77 Prosecutor v. Bagosora et al., ICTR-98-41-T, Decision on Defence Motion for Reconsideration of the Trial Chamber's Decision and Scheduling Order of 5 December 2001, July 18, 2003 (hereinafter Bagosora 2003 Decision), ๆ 15,

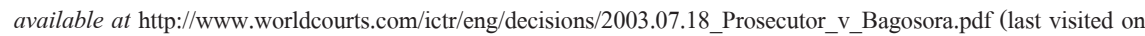
May 8, 2016).
} 
informed of the entirety of their statements.",78

Numerous decisions of the ICTR still require that the identity of witnesses be disclosed before the commencement of the trial, particularly in the trials of a single accused, where there is little likelihood of a long delay between the disclosure of the witnesses' identity and their testimony. ${ }^{79}$ In general, 'rolling disclosure' has been permitted in the larger cases. For determining an appropriate rolling disclosure timeline, the ICTR Chambers took into account "general security situation in Rwanda" and "the specific risks faced by victims and potential witnesses." Many decisions which permitted rolling disclosure have determined "no later than twenty-one (21) days prior to the witness' testimony" as an 'adequate time' under Rule $69(\mathrm{C}){ }^{81}$ In other cases where rolling disclosure was denied or outside the requests of the prosecutor, "thirty (30) days prior to the commencement of the trial" 82 or "twenty-one (21) days prior to the commencement of the trial" ${ }^{\prime 83}$ have been ordered under Rule 69(C).

\section{Conclusion}

Being present as human person in the middle of egregious atrocities of such a level as occurred in the former Yugoslavia and Rwanda, regardless of whether as a victim or as a member a perpetrator group, is certainly something beyond imagination

78 Simba Decision, supra note 13, \6; Gatete Decision, supra note 13, at 9 ; Bagosora 2003 Decision, supra note 77, $\uparrow$ 15 .

79 Prosecutor v. Kanyarukiga, ICTR-2002-78-1, Decision on Prosecution Motion for Protective Measures, June 3, 2005 (hereinafter Kanyarukiga Decision), at ๆ 5, available at https://www.legal-tools.org/uploads/tx_ltpdb/KanyarukigaICTRSingleJudgeDecisiononProsecutionMotionforProtectiveMeasures_03-06-2005_E_05.html; Prosecutor v. Nsengimana, ICTR-2001-69-T, Decision on the Prosecutor's Motion for Protective Measures for Witnesses, Sept. 2, 2002, at 7, available at https:/www.legal-tools.org/uploads/tx_ltpdb/Nsengimana-ICTRTCDecisionontheProsecutors MotionforProtectiveMeasuresforWitnesses_02-09-2002__E__05.html (all last visited on May 8, 2016).

80 Renzaho Decision, supra note 29 , at $\uparrow 15$.

81 Prosecutor v. Kajelijeli, ICTR-98-44A-T, Decision on Juvénal Kajelijeli's Motion for Protective Measures for Defence Witnesses, Apr. 3, 2001, ๆ 20, available at https://www.legal-tools.org/uploads/tx_ltpdb/Kajelijeli-ICTRTCDecisi ononJuvenalKajelijelisMotionforProtectiveMeasuresforDefenceWitnesses_03-04-2001_E_05.pdf; Prosecutor v. Mpambara, ICTR-01-65-I, Decision (Prosecutor's Motion for Protective Measures for Prosecution Witnesses), May 29, 2002, ब 18, available at https://www.legal-tools.org/uploads/tx_ltpdb/doc35588.pdf; Prosecutor v. Niyitegeka, ICTR-96-14-I, Decision on the Prosecutor's Motion for Protective Measures for Witnesses, July 12, 2000, ๆ 16, available at $\mathrm{https}$ //www.legal-tools.org/uploads/tx_ltpdb/Niyitegeka-ICTRTCDecisionontheProsecutorsMotionforProt ectiveMeasuresforWitnesses_12-07-2000_E_ 09.html (all last visited on May 8, 2016).

82 Simba Decision, supra note 13, at 7 ; Kanyarukiga Decision, supra note 79, at 5.

83 Gatete Decision, supra note 13 , at 97. 
for most of people. Furthermore, being in an international courtroom as a victim witness or an insider witness facing the person charged with core international crimes is very likely to be re-traumatizing. Most seriously, in a society still shaky and unstable after mass atrocity, threats to a witness from governmental or military officials, neighbors and even from the witness's own family members are surely conceivable. ${ }^{84}$ As to international criminal proceedings, what should be considered is the extraordinary length and frequent delays which renders it justifiable and even necessary to introduce such an exceptional scheme like 'rolling disclosure' at the ad hoc international criminal tribunals. In this context, notwithstanding the urgent need to respect the rights of the accused, inter alia, his right to have adequate time to prepare a defence, ${ }^{85}$ the practice of 'delayed disclosure' appears rather to be a necessary evil. As an extraordinary justice mechanism dealing with extraordinary crimes, the jurisprudence of the ICTY and the ICTR in respect of 'delayed disclosure' demonstrates well the exceptional judicial challenges that both tribunals had to face in striking a balance between the two crucial interests of the accused and those of the witnesses.

84 See Testifying to Genocide: Victim and Witness Protection in Rwanda, The REDRESS Trust, at 24-9, available at http://protectionline.org/files/2012/11/121029ProtectionReport.pdf. Recently, the ICC Trial Chamber in Bemba lamented that: "This information suggests that the identities of prosecution witnesses have been revealed in situations where the Chamber has granted protective measures to protect their identities. [...] The Chamber was provided with a letter from [a witness reporting] death threats directed at him and his family as a result of his cooperation with the Court." See Prosecutor v. Bemba, ICC-01/05-01/08, Public Redacted Version of the 26 September 2011 Decision on the accused's application for provisional release in light of the Appeals Chamber's judgment of 19 August 2011, Sept. 27, 2011, at 9 30, available at https://www.legal-tools.org/uploads/tx_ltpdb/doc1237130_04.pdf (all last visited on May 8, 2016). See also numerous examples of harm inflicted or threatened to be inflicted upon the witnesses before international criminal tribunals, see BOAS ET AL, supra note 2, at 267 (n. 97).

85 Practically, it is the accused's right to cross-examine the prosecution witnesses that is most likely to be infringed by the practice of delayed disclosure. For details on the cross-examination in the context of the peculiar Rwandan oral culture of explaining events as if they were observed firsthand, see Pozen, supra note 2, at 308-10. 
